\title{
Physicochemical Characteristics and Health Risk Assessment of Drinking Water Sources in Okoroette Community, Eastern Coast of Nigeria
}

\author{
Edu Inam ${ }^{1,2, *}$, Gerald G. Inoh ${ }^{3}$, Nnanake-Abasi O. Offiong ${ }^{1,2}$, Bassey B. Etim ${ }^{4}$ \\ ${ }^{1}$ Department of Chemistry, University of Uyo, Uyo, Nigeria \\ ${ }^{2}$ Centre for Energy and Environmental Sustainability Research (CEESR), University of Uyo, Uyo, Nigeria \\ ${ }^{3}$ Ministry of Science and Technology, Akwa Ibom State, Nigeria \\ ${ }^{4}$ Department of Civil Engineering, University of Uyo, Uyo, Nigeria \\ *Corresponding author: eduinam@uniuyo.edu.ng
}

\begin{abstract}
The coastal region of Nigeria has witnessed intense anthropogenic activities that have overtime necessitated several environmental monitoring campaigns to ascertain impacts and proffer remedial solutions. In the present study, standard analytical protocols were employed to assess the physicochemical parameters, trace metals and polycyclic aromatic hydrocarbons (PAHs) levels of ground and surface water used for drinking purposes in Okoroette community in Nigeria. The results obtained show that investigated parameters varied widely and were generally higher in the surface water samples collected during the dry season. The levels of most of the physicochemical parameters recorded were acceptable when compared with Nigerian Standards for Drinking Water Quality (NSDWQ) except for turbidity and dissolved oxygen. In both ground and surface waters, the following trace metals exceeded the NSDWQ permissible limits: $\mathrm{Pb}, \mathrm{Cd}, \mathrm{Fe}$, and $\mathrm{Mn}$. The total mean level of PAHs (> $1.0 \mathrm{mg} / \mathrm{l})$ in both ground and surface water samples exceeded the acceptable level when compared with the NSDWQ guideline value of $0.007 \mathrm{mg} / \mathrm{l}$. The health risk assessment applied on trace metal levels reveal that there is significant potential toxic risk to exposed individuals as calculated hazard indexes (HI) were greater than one. Results from Water Quality Indices (WQI) modelling reveal that the water sources in the community were generally categorised as poor quality or unfit for drinking purposes. Chemometric characterisation of the water quality indicators revealed that some of the contaminants may be of geogenic, anthropogenic organic in origin. The study reveals that drinking water sources in Okoroette community are not suitable for consumption and domestic use therefore treatment is highly and urgently recommended to safeguard public health.
\end{abstract}

Keywords: water quality, health risk assessment, trace metals, PAHs, chemometrics, modelling

Cite This Article: Edu Inam, Gerald G. Inoh, Nnanake-Abasi O. Offiong, and Bassey B. Etim, "Physicochemical Characteristics and Health Risk Assessment of Drinking Water Sources in Okoroette Community, Eastern Coast of Nigeria.” American Journal of Water Resources, vol. 5, no. 1 (2017): 13-23. doi: 10.12691/ajwr-5-1-3.

\section{Introduction}

A primary concern of people living in developing countries is that of obtaining clean drinking water which is one of the most important natural resource on earth. In Africa, most people in rural areas depend on ground and surface water for sustenance. The situation is not different in Nigeria, particularly in the rural areas like Okoroette community. Nigeria is one of the worst in the world for household water access and ranked 3rd on the list of the top 10 countries with the greatest numbers of people living without access to safe water [1]. The authors also opined that about 29 per cent of Nigeria's population has access to basic sanitation. Nigeria is one of a handful of countries around the world where access to basic sanitation is falling rather than rising. About 25 per cent practice open defecation while 31 per cent lack access to improved water sources. Similarly, around 68,000 children under the age of five in Nigeria die from diseases caused by the nation's poor levels of access to water, sanitation and hygiene [2]. There have been reports of water contamination in the Niger Delta region of Nigeria as a result of oil and gas exploration activities [3]. Okoroette being one of the Niger Delta communities is no exception.

The community has an estimated population size of about three thousand people and the major economic activities are fishing and farming. However its environment is remarkably impacted by oil exploration activities. Like most of the coastal communities affected by oil exploration in the Niger Delta, clean water is a major challenge for the people. Most water sources are contaminated with hydrocarbon thereby compelling the inhabitant, to depend largely on water from seasonal ponds, streams and few boreholes with quality not evaluated. Preliminary survey reveal that the hygienic 
condition of drinking water sources in Okoroette is poor resulting in reported cases of water borne diseases at health centres. The consequences of these diseases may result in low quality of life, reduced life expectancy and brings about economic retrogression. An assessment of underground and surface water quality in Okorotte community would lend useful clues to the quality of water used for drinking and domestic purposes. It would also furnish invaluable facts and figures that would form the basis for any meaningful interventions that would protect the health of the people. Therefore, the aim of this work was to evaluate the quality of drinking water sources in Okoroette community for the protection of human health.

\section{Material and Methods}

\subsection{Description of the Study Area}

Okoroette is a riverine community situated in Eastern Obolo Local Government Area of Akwa Ibom State located in the Niger Delta fringe between Imo and Qua Iboe River estuaries. It lies between latitudes $4^{\circ} 28^{\prime}$ and $4^{\circ} 53^{`}$ and longitudes $7^{\circ} 50^{`}$ and $7^{\circ} 55^{\prime}$ east (Figure 1 ). The land mass of Okoroette community is 8,040 square kilometres with an estimated shoreline of about $4 \mathrm{~km}$ long. The 2006 national population census estimated population size of about three thousand people and their major economic activities are fishing and farming. There are abundant mineral deposits with onshore and offshore oil wells and fish depots.

\subsection{Sample Collection}

Water samples were collected for analysis from eight sampling stations representing four (4) boreholes and four (4) streams used for drinking and domestic purposes. Samples were collected and analysed during dry and wet seasons. Samples for organic analysis were collected using amber bottles. For physicochemical and trace metals parameters, samples were collected into $500 \mathrm{ml}$ plastic bottles. All samples were stored in a cooler containing ice cubes and transported to the laboratory.

\subsection{Sample Pre-treatment, in Situ Analysis and Storage}

The American Society for Testing and Materials (ASTM) [4] and Standard Methods for the Evaluation of Water and Waste Water by the American Public Health (APHA) [5] were applied to all sample collections, preparation and analysis. Samples for trace metals determination were acidified with a mixture of $\mathrm{HNO}_{3}$ and $\mathrm{HCl}(1: 1, \mathrm{v} / \mathrm{v})$. Immediate measurement and analysis were carried out on each sample to determine in-situ parameters such as $\mathrm{pH}$, temperature, electrical conductivity (EC), dissolved oxygen (DO) and turbidity [6]. The $\mathrm{pH}$ was measured using the $\mathrm{pH}$ meter appropriately standardised according to the manufacturer's instruction, while the temperature of the samples was measured by means of temperature meter. Electrical conductivity (EC) was measured using a calibrated conductivity meter. Total dissolved solids and dissolved oxygen were measured in situ using calibrated Hanna series of their respective metres.

\subsection{Digestion Method for Trace Analysis}

Samples were well shaken to homogenise before sub-sampling for digestion. Exactly $50 \mathrm{ml}$ sub-samples were measured into a digestion beaker of $250 \mathrm{ml}$ capacity and $1 \mathrm{ml}$ of concentrated $\mathrm{HNO}_{3}$ and $0.5 \mathrm{ml}$ of concentrated $\mathrm{HCl}$ were added to each sample. The content of the beaker was heated using water bath in a fume cupboard for $2-2.5$ hours at $95^{\circ} \mathrm{C}$. The samples were then removed from the heat source and cooled for 30 minutes. The digested samples were made up to $50 \mathrm{ml}$ with distilled water and were shaken to mix and filtered using $19.0 \mathrm{~cm}$ Whatman No. 42 filter paper to remove suspended matter. The digested water samples were then ready for trace metals determination.

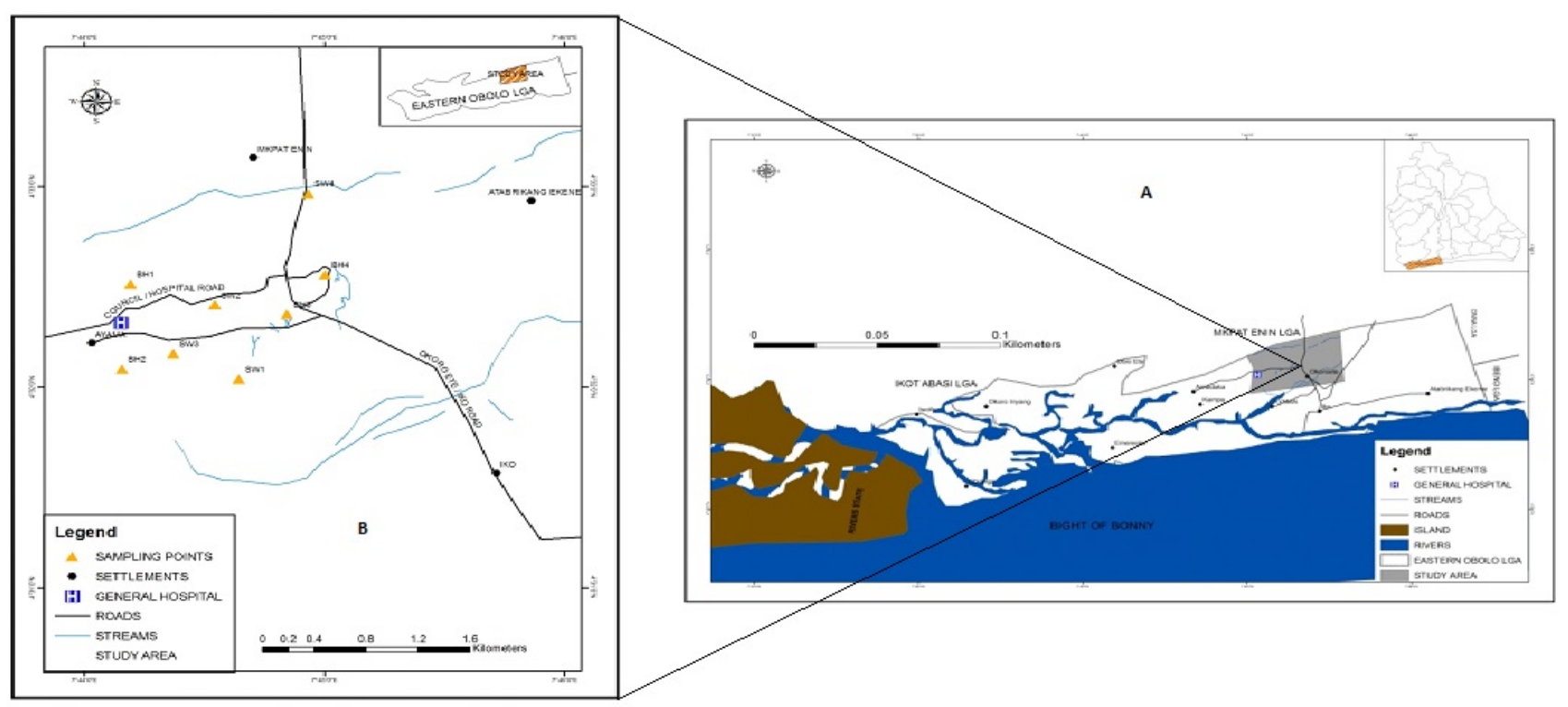

Figure 1. Eastern Obolo Area showing Okoroette Community (Eastern Coast of Nigeria) (A) and sampling sites (B) 


\subsection{Determination of Physicochemical Parameters}

Physicochemical characteristics of water samples including $\mathrm{pH}$, temperature, electrical conductivity, turbidity, dissolved oxygen, biological oxygen demand, and total dissolved solids were determined. The $\mathrm{pH}$, electrical conductivity, total dissolved solids and temperature were determined using Hanna environmental probe (H Series). The turbidity was determined by nephelometry method [7].

The dissolved oxygen (DO) of the samples was determined using a DO meter (Hanna H19146-04). Later, the sample was then incubated in the dark at $25^{\circ} \mathrm{C}$ for 5 days and the $\mathrm{DO}_{5}$ measurement taken. The difference between the initial $\mathrm{DO}\left(\mathrm{DO}_{1}\right)$, and the $\mathrm{DO}_{5}$ gave the BOD of the sample [7]. For the determination of the total suspended solids (TSS), constant weight of the filter paper (dried in an oven at $150^{\circ} \mathrm{C}$ for one hour) was taken and used for filtering a known volume of the water sample. The filter paper was then transferred into a desiccator to cool for one hour. The final and constant weight of the filter paper was taken and the result recorded [4]. The total hardness was determined using a method described by ASTM [4]. A known volume of the sample was measured into $250 \mathrm{ml}$ dried conical flask. Exactly $2 \mathrm{ml}$ of ammonia buffer solution and 1 tablet of total hardness indicator were added into the sample and mixed. The solution was then titrated with $0.02 \mathrm{~N}$ EDTA solution to a blue colour end point from which the total hardness values were derived and recorded. The salinity of the sample was determined according to ASTM [4]. A known volume of the sample was transferred into a $250 \mathrm{ml}$ dried conical flask. 2-3 drops of $\mathrm{K}_{2} \mathrm{CrO}_{4}$ was added into the flask, swirled and then titrated with $0.1 \mathrm{~N} \mathrm{AgNO}_{3}$ to a brick - red end point from which the values were derived and recorded. Nitrate was determined using ASTM [4] method using a uv-vis spectrophotometer (DR/3800) at wavelength of $500 \mathrm{~nm}$. Nitrite concentration in the sample was determined using the same spectrophotometer but at wavelength of $507 \mathrm{~nm}$. The concentration of sulphate in the water sample was determined using spectrophotometer (DR/3800) at wavelength of $450 \mathrm{~nm}$. The program number for sulphate was selected and the wavelength set to $450 \mathrm{~nm}$. The spectro UV -Vis 2500 spectrophotometer was used for the determination total hydrocarbon content (THC) in the water samples according to ASTM method [4] at the wavelength of 425 $\mathrm{nm}$.

\subsection{Determination of Trace Metals}

The trace metals were determined using the atomic absorption spectrometer (UNICAM 969AA). The standards for each metal were prepared. The deionised water was aspirated for zero absorbance and followed by the blank. The standards and already prepared samples in their sequence as identified were equally aspirated and the concentration values of each sample displayed was recorded. Finally quality control check was performed by aspirating a known concentration of the metal being determined [4].

\subsection{Determination of Polycyclic Aromatic Hydrocarbons (PAHs)}

Analysis of PAHs in the water samples was conducted using a modified method previously reported [8]. One litre of the water sample was acidified to $\mathrm{pH} 2$ with $5 \mathrm{~mol} / \mathrm{l}$ $\mathrm{H}_{2} \mathrm{SO}_{4}$. The water sample was not filtered. One hundred nanogram of internal standard mix (Restek) was added to the sample. Liquid-liquid extraction with $30 \mathrm{ml}$ n-hexane was applied three times. The extract was dried using anhydrous sodium sulphate and concentrated to $1 \mathrm{ml}$ by a rotary evaporator. The PAH compounds in the concentrated extract were fractionated by a silica gel column $(200 \mathrm{~mm}$ long, $4 \mathrm{~mm}$ internal diameter). The column was first eluted with $30 \mathrm{ml}$ of n-hexane and the eluate was discarded. Further elution was carried out with $30 \mathrm{ml}$ of dichloromethane to obtain the PAH fraction. The fraction containing the PAHs was concentrated to $1 \mathrm{ml}$ by using a rotary evaporator. A gas chromatography-mass spectrometry (GC/MS) system consisting of an Agilent 6890 gas chromatograph with a GC column (30 m long, $0.25 \mathrm{~mm}$ internal diameter, 0.25 $\mu \mathrm{m}$ coating, $5 \%$ diphenyl - $95 \%$ dimethyl polysiloxane) and an Agilent 5973 mass spectrometer was used for the analysis. Helium was used as the carrier gas, and the flow rate was maintained at $1.4 \mathrm{~mL} / \mathrm{min}$ (linear velocity of $43 \mathrm{~cm} / \mathrm{s}$ ). One microlitre sample volume was injected by applying a splitless injection technique. The temperature of the GC injector port was maintained at $250^{\circ} \mathrm{C}$. The temperature of the column was programmed from the initial $45^{\circ} \mathrm{C}$ to $300^{\circ} \mathrm{C}$ at a rate of $8^{\circ} \mathrm{C} / \mathrm{min}$. The mass selective detector was operated in the electron impact mode using $70 \mathrm{eV}$. Ion source temperature was $230^{\circ} \mathrm{C}$. Selected ion monitoring mode was employed for the identification and quantification of the 16 individual PAH compounds. Limit of detection of about $1 \mathrm{ng} / \mathrm{L}$ was achieved using the system described for the $16 \mathrm{PAH}$ compounds examined. The total PAH concentration was regarded as the sum of the concentrations of $16 \mathrm{PAH}$ species ( $\Sigma \mathrm{PAHs}$ ) for each collected sample. Quality control and assurance obtained for the PAHs analysis method have been described in detail in previous publication [9].

\subsection{Risk Assessment of Trace Metals}

A comprehensive risk assessment process which consists of four distinct phases: (1) hazard identification; (2) exposure assessment; (3) dose-response assessment; and (4) risk characterization was applied accordingly. This basic frame-work was adopted for assessing the health risks to an adult and a child who reside in the studied area and are exposed to the trace elements present in the water sources through ingestion pathway. The hazard identification process was carried out through the collection of samples and subsequent determination of the contamination level of the trace elements in the samples. In order to estimate non-carcinogenic risks, dose-response assessment was done using standard reference dose (RfD) values for the trace metals considered in this study.

\subsubsection{Exposure Assessment}

The chronic daily intake (CDI) through the drinking was calculated using the modified equation previously reported [10] and as shown in equation 1 . 


$$
C D I=\frac{C \times D I}{B W}
$$

where, C, DI and BW represent the concentration of trace metals in water $\left(\mu \mathrm{g} \mathrm{dm}^{-3}\right)$, average daily intake rate ( $2 \mathrm{dm}^{-3} /$ day for an adult and $1 \mathrm{dm}^{-3} /$ day for a child) and average body weight (72 kg for an adult and $10 \mathrm{~kg}$ for a child) respectively [11].

\subsubsection{Evaluation of Non-Cancer (Toxic) Risk}

The magnitude of harm is estimated in terms of a hazard quotient (HQ) as expressed in the equation from Shah et al. [12] and as shown in equation 2:

$$
H Q=\frac{C D I}{R f D}
$$

where, according to USEPA database, the oral toxicity reference dose values (RfD) are 1.8E-01, 5.0E-04, 3.7E-02, 8.0E-01, 1.4E-01, 3.6E-02, 3.0E-01 mg/kg-day for Al, Cd, $\mathrm{Cu}, \mathrm{Fe}, \mathrm{Mn}, \mathrm{Pb}$, and $\mathrm{Zn}$ respectively $[13,14]$. The exposed population is assumed to be safe when $\mathrm{HQ}<1[15,16]$. The reference dose is the daily dosage that enables the exposed individual to sustain a certain level of exposure over an elongated period of time with detrimental effect. The toxic risk estimates are based on a comparison of actual exposure to the reference dose for the particular chemical involved [17].

In the case where the potential toxicants are more than one, their interactions must be considered. The toxic risks due to potentially hazardous chemicals in the same medium are assumed to be cumulative. The HQs would then be added to obtain the overall toxic risk, the hazard index (HI) [18] that:

$$
H I=\Sigma H Q_{i}, i=1, \ldots n .
$$

If the calculated $\mathrm{HI}$ is less than 1.0, the noncarcinogenic adverse effect due to this exposure pathway or chemical is assumed to be negligible.

\subsection{Calculation of Water Quality Index}

The water quality index (WQI) model simplifies the presentation of results of an investigation related to a water body as it summarises in one value or concept a series of parameters analysed [19]. This way, the indices are very useful to transmit information relating to water quality to the public in general, and give a good idea of the evolution tendency of water quality to evolve over a period of time. A single WQI value makes information more easily and rapidly understood than a long list of numerical values for a large variety of parameters. More so, WQI also facilitates comparison between different sampling sites and events. In this study, for the calculation water quality index, ten important parameters were chosen. The weighted arithmetic index method [19] has been used for the calculation of WQI in this study. Further, quality rating or sub index was calculated using the following expression.

$$
q n=100[\text { Vn }- \text { Vio }] /[S n-V i o] .
$$

Let there be $n$ number of water quality parameters and quality rating ( $q n)$ corresponding to nth parameter is a number reflecting relative value of this parameter in the polluted water with respect to its standard permissible value;

$q n=$ Quality rating for the $n^{\text {th }}$ Water quality parameter

$V n=$ Estimated value of the $n^{\text {th }}$ parameter at a given water sampling station

$S n=$ Standard permissible value of the $n^{\text {th }}$ parameter

Vio $=$ Ideal value of $n^{\text {th }}$ parameter in pure water (i.e., 0 for all other parameters except the parameters $\mathrm{pH}$ and Dissolve oxygen [7.0 and $14.6 \mathrm{mg} / \mathrm{l}$ respectively]). The unit weight was calculated by a value inversely proportional to the recommended standard value $S n$ of the corresponding parameter.

$$
W n=k / S n
$$

Where;

$W n=$ unit weight for $\mathrm{n}^{\text {th }}$ parameter

$S n=$ standard permissible value for $n^{\text {th }}$ parameter

$\mathrm{k}=$ proportionality constant. The overall WQI is calculated by the following equation.

$$
W Q I=\Sigma q n W n / \Sigma W n .
$$

The suitability of WQI values for human consumption according to Table 1 [19].

\subsection{Statistical Analysis}

The descriptive statistics were performed using Excel 2007 spreadsheet while multivariate analyses were done using the Statistical Package for Social Sciences (SPSS) software Version 20.0. Analyses of variance (ANOVA) at 95\% confidence level were used to determine the significant difference at $p \leq 0.05$.

\section{Results and Discussion}

\subsection{Physicochemical Characteristics}

The results of the physicochemical characteristics of samples collected from drinking water sources in Okoroette Community are presented in Table 2. The values were compared with World Health Organisation (WHO), Irish Environmental Protection Agency (IEPA) and Nigerian Standard for Drinking Water Quality (NSDWQ) [20,21,22]. The water samples were mostly cloudy with inoffensive odour.

The temperature ranged from $26.9^{\circ} \mathrm{C}$ to $28.9^{\circ} \mathrm{C}$ with the least value observed in ground water sample during the wet season. The maximum value was recorded for surface water sample during the dry season. The temperature values were within the applicable regulation which requires ambient levels.

Table 1. Water quality index and quality of water

\begin{tabular}{ll}
\hline Water quality index level & Water quality status \\
\hline $0-25$ & Excellent water quality \\
$25-50$ & Good water quality \\
$51-75$ & Poor water quality \\
$76-100$ & Very poor water quality \\
$>100$ & Unsuitable for drinking \\
\hline
\end{tabular}


Table 2. Result of Physicochemical characteristics (mean \pm STD) of drinking water sources in Okoroette Community

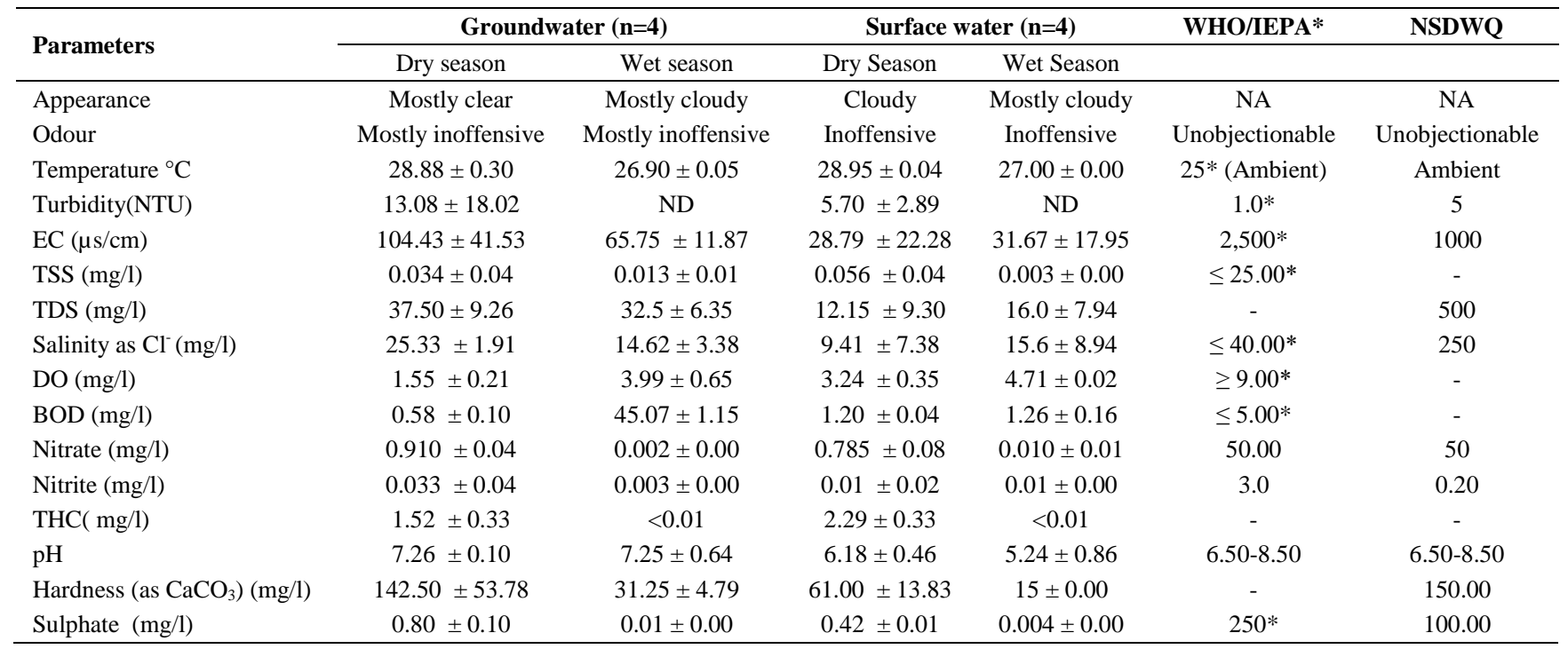

The maximum turbidity level (13.08 NTU) was recorded for ground water samples during the dry season. The lowest value was recorded for surface water during the dry season. These values were in compliance with the NSDWQ requirements but unacceptable within the IEPA regulation.

The values of the total suspended solids (TSS) were maximum $(0.056 \mathrm{mg} / \mathrm{l})$ and lowest $(0.003 \mathrm{mg} / \mathrm{l})$ for surface water samples during the dry and wet seasons respectively. These recorded values are within acceptable standards (Table 2).

The groundwater samples recorded highest values for total dissolved solids (TDS) in both dry and wet seasons (37.50 mg/l and $32.50 \mathrm{mg} / \mathrm{l}$ respectively). The lowest values were obtained for the surface water although with the maximum during wet season. This is expected as inputs from surface runoffs and storm water may lead to increased dissolved substances. Nevertheless, the recorded values complied with applicable standards.

The salinity as chloride determined were lowest (12.15 mg/l) in the surface water during the dry season. This further confirms the hypothesis on dissolved mineral matter in the groundwater which resulted in high electrical conductivity and total dissolved solids. The recorded values were within permissible limits.

The recorded dissolved oxygen (DO) values were low. The lowest recorded value $(1.55 \mathrm{mg} / \mathrm{l})$ was for the groundwater samples during the dry season while the maximum was $(4.70 \mathrm{mg} / \mathrm{l})$ recorded for surface water samples during the wet season. Although the NSDWQ guideline has not defined the range of acceptable values for DO, the IEPA gives a requirement of $\geq 9.00 \mathrm{mg} / \mathrm{l}$. The $\mathrm{DO}$ values recorded in this study were unacceptable under the IEPA requirements. The low DO values indicate poor water quality and may result in oxygen deficiency to sustain aquatic life.

The recorded biochemical oxygen demand (BOD) values were abnormally high $(45.07 \mathrm{mg} / \mathrm{l})$ in ground water samples during the wet season while the lowest $(0.58 \mathrm{mg} / \mathrm{l})$ was recorded during the dry season in the same groundwater samples. The values recorded for the surface water samples were $1.20 \mathrm{mg} / \mathrm{l}$ and $1.26 \mathrm{mg} / \mathrm{l}$ for both dry and wet seasons, respectively. Generally, the IEPA requires the BOD to be $\leq 5.00 \mathrm{mg} / \mathrm{l}$, although the result obtained for groundwater samples in the wet season exceeded by a great magnitude. The implication of high BOD indicates poor water quality with possible organic pollution.

The recorded values of the nitrate levels in the samples revealed maximum concentration $(0.91 \mathrm{mg} / \mathrm{l})$ in groundwater during the dry season and lowest $(0.010 \mathrm{mg} / \mathrm{l})$ during the wet season in the same samples. The same trend was recorded for nitrite concentrations. Values recorded for both parameters were within the acceptable limits defined by WHO and NSDWQ guidelines.

The highest mean value of the total hydrocarbon content (THC) recorded was $2.29 \mathrm{mg} / \mathrm{l}$ for surface water samples during the dry season. The lowest value $(1.52 \mathrm{mg} / \mathrm{l})$ was recorded for groundwater samples during the dry season. Higher levels of THC in the surface water may be due to inputs from surface runoffs [26]. Although the WHO, IEPA and NSDWQ guidelines do not specify the permissible limits for THC in drinking water, the Nigerian Federal Ministry of Environment [23] gives a maximum allowable limit of $10 \mathrm{mg} / \mathrm{l}$ of which the recorded values obtained in this study are acceptable.

The $\mathrm{pH}$ values were lowest in the surface water samples signifying acidity; 6.18 and 5.24 for dry and wet seasons respectively. Values recorded for groundwater were higher; 7.26 and 7.25 for dry and wet seasons respectively. The low $\mathrm{pH}$ values recorded for the surface water samples may be due to acidification from atmospheric carbon dioxide exchange [24].

The mean values of total hardness as calcium carbonate were higher during the dry season in both groundwater (142.50 mg/l) and surface water (61.00 mg/l). Lower concentrations were observed during the wet season: $31.25 \mathrm{mg} / \mathrm{l}$ and $15.00 \mathrm{mg} / \mathrm{l}$ for groundwater and surface water respectively. The observed levels were within the acceptable limits of the NSDWQ guidelines.

The maximum sulphate level $(0.8 \mathrm{mg} / \mathrm{l})$ was recorded for groundwater samples during the dry season while the lowest $(0.004 \mathrm{mg} / \mathrm{l})$ was recorded for surface water samples in the wet season. The relatively high sulphate level in the groundwater may be due to corresponding high mineral matter content signified by high TDS recorded. Overall, the sulphate levels were within acceptable limits by IEPA and NSDWQ guidelines. 
Generally, the physicochemical characteristics of drinking water sources in the Okoroette Community are varied as indicated in Figure 2 and are comparable with the results obtained from other studies within the Niger Delta region of Nigeria [25,26]. However, Owamah et al. [27] recorded relatively high levels of DO (13 mg/l) and TDS (144mg/l) for groundwater samples from Isoko North. Also, higher conductivity values (up to $813 \mu \mathrm{s} / \mathrm{cm}$ ) were recorded for groundwater samples from Abeokuta [28]. Udousoro and Ikpeme [29] reported relatively lower levels $(0.15 \mathrm{mg} / \mathrm{l})$ of nitrate from surface water quality assessment in Uruan. In the same manner, Udosen [30] reported slightly low temperature levels (mostly $24^{\circ} \mathrm{C}$ ) for surface water samples from Ikpa River. Itah and Akpan [31] reported lower values (2-6mg/l) for chloride concentration in drinking water samples from Eastern Obolo area. All these changes are due to temporal, spatial and environmental dynamics.

\subsection{Trace Metals Levels}

The levels of trace metals in the ground and surface water use for drinking purposes in Okoroette community are presented in Table 3. Generally, the trace metals levels were higher during the dry season. Aluminium was not detected in all the samples analysed. Cumulatively, the levels of trace metals were highest in the groundwater samples than surface water samples.

The maximum recorded level $(0.17 \mathrm{mg} / \mathrm{l})$ for lead was observed in groundwater samples during the dry season. The lowest $(0.04 \mathrm{mg} / \mathrm{l})$ was observed in the surface water samples during wet season. All the recorded levels exceeded acceptable limits $(0.01 \mathrm{mg} / \mathrm{l})$ for drinking water quality. A similar trend was observed for cadmium with the highest $(0.81 \mathrm{mg} / \mathrm{l})$ and lowest levels $(0.24 \mathrm{mg} / \mathrm{l})$ in groundwater samples during the dry season and surface water sample during the wet season.

Copper levels $(0.40 \mathrm{mg} / \mathrm{l}$ and $0.41 \mathrm{mg} / \mathrm{l})$ were almost the same in both ground and surface waters respectively.
However, Cu was not detected in all samples during the wet season. The levels observed were within acceptable limits by WHO and NSDWQ guidelines.

The levels of iron in the analysed samples generally were within acceptable limits of WHO but some were unacceptable under the NSDWQ guidelines (Table 3). Highest level $(0.96 \mathrm{mg} / \mathrm{l})$ recorded was in groundwater during the wet season. The lowest $(0.04 \mathrm{mg} / \mathrm{l})$ was also recorded in groundwater but during the dry season.

The highest mean level $(1.10 \mathrm{mg} / \mathrm{l})$ of manganese was observed in the surface water samples during the dry season. The lowest level $(0.35 \mathrm{mg} / \mathrm{l})$ was recorded for both ground and surface water samples during the wet season. All the recorded levels exceeded the acceptable limits for drinking water quality under the NSDWQ guideline. Zinc level was highest $(0.92 \mathrm{mg} / \mathrm{l})$ in the groundwater during the wet season and lowest $(0.49 \mathrm{mg} / \mathrm{l})$ in surface water samples during the wet season. All the recorded values were within the permissible limits of the NSDWQ guidelines.

The result reveals that the drinking water sources in Okorette are contaminated by $\mathrm{Pb}, \mathrm{Mn}$ and $\mathrm{Cd}$. A graphical representation of the trace metals levels in comparison with permissible values are presented in Figure 3. The higher levels recorded for groundwater samples contains serious contamination which may be as a result of anthropogenic activities within the area or geologic migration of the metals. Itah and Akpan [31] had previously reported the abnormally high levels of these metals in the ground water samples from the study area. Present study has further revealed temporal increase in the levels of these toxic metals. This poses a serious threat to public health of the inhabitants of this area who drink from these water sources. For instance, lead and cadmium have the ability to cause one or more of the following: cancer, headache, abdominal pain, nerve damage, kidney damage, influence blood pressure, causes gastrointentinal effects, constipation, bone pain, convulsion, fatigue, causes brain damage and cognitive deficits, causes insomnia, anorexia and muscle irritability [16,32,33].
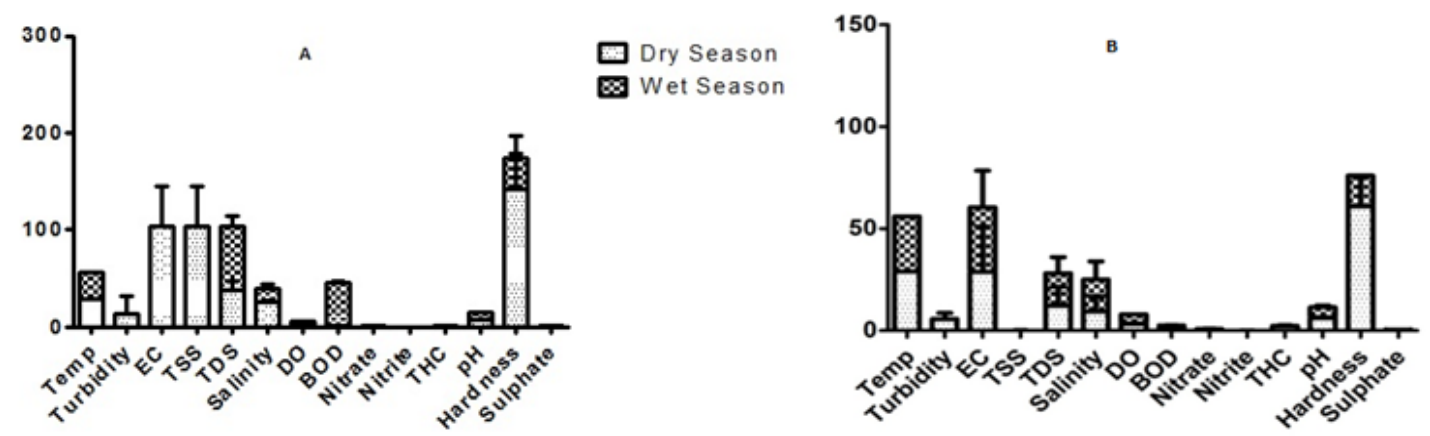

Figure 2. Variation in physicochemical characteristics of ground (A) and surface (B) drinking water sources in Okoroette community

Table 3. Levels of some trace metals (mg/l) in drinking water samples collected from Okoroette community

\begin{tabular}{|c|c|c|c|c|c|c|}
\hline \multirow{2}{*}{ Trace metals } & \multicolumn{2}{|c|}{ Groundwater $(n=4)$} & \multicolumn{2}{|c|}{ Surface water $(n=4)$} & \multirow{2}{*}{ WHO } & \multirow{2}{*}{ NSDWQ } \\
\hline & Dry season & Wet season & Dry Season & Wet Season & & \\
\hline Lead & $0.17 \pm 0.01$ & $0.10 \pm 0.01$ & $0.04 \pm 0.02$ & $<0.001$ & 0.01 & 0.01 \\
\hline Cadmium & $0.81 \pm 0.31$ & $1.30 \pm 0.28$ & $0.32 \pm 0.01$ & $0.24 \pm 0.21$ & 0.003 & 0.003 \\
\hline Copper & $0.41 \pm 0.26$ & $<0.001$ & $0.40 \pm 0.05$ & $<0.001$ & 2.00 & 1.00 \\
\hline Aluminium & $<0.001$ & $<0.001$ & $<0.001$ & $<0.001$ & - & 0.20 \\
\hline Iron & $0.04 \pm 0.97$ & $0.96 \pm 0.95$ & $0.98 \pm 0.61$ & $0.30 \pm 0.07$ & 1.00 & 0.30 \\
\hline Zinc & $0.58 \pm 0.24$ & $0.92 \pm 0.06$ & $0.79 \pm 0.06$ & $0.49 \pm 0.10$ & - & 3.00 \\
\hline
\end{tabular}




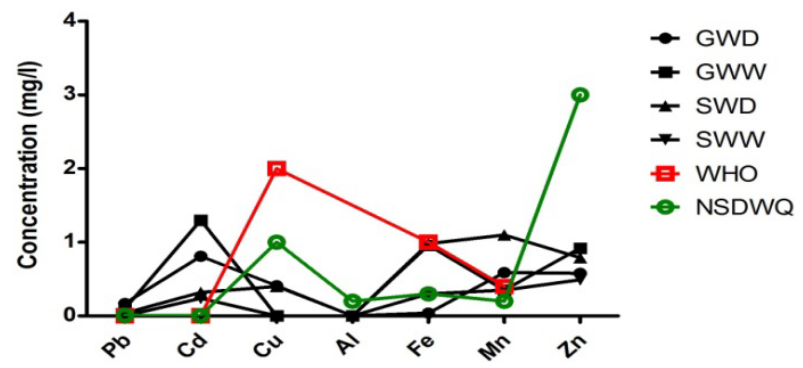

Figure 3. Comparison of trace metals levels with standards (GWD groundwater in dry season; GWW -groundwater in wet season; SWD surface water in dry season; SWW -surface water in wet season)

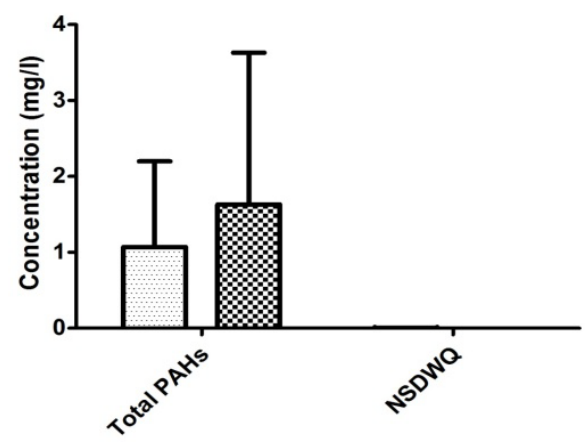

Ground Water $\otimes$ Surface Water

Figure 4. Levels of PAHs in comparison with Nigerian Drinking Water Quality Standard (NSDWQ)

\subsection{Levels of Polycyclic Aromatic Hydrocarbons (PAHs)}

The level of 16 USEPA priority PAHs quantified in the ground and surface water samples from the study area are presented in Table 4. A graphical representation of the total PAHs level in comparison with the NSDWQ guideline values is presented in Figure 4. The PAHs profiles in the ground and surface water samples are very similar (Figure 5) except for the slight increment in concentrations of the 5-ring compounds (BbF, BkF and $\mathrm{BaP})$. However, these small amounts $(0.003 \mathrm{mg} / \mathrm{l}$ each) may be ignored as the values are close to the method detection limit of $0.001 \mathrm{mg} / \mathrm{l}$. This similarity in the PAHs composition profile suggests the same source of contamination. The majority of individual $\mathrm{PAH}$ compounds detected belong to the 3-ringed low molecular weight (LMW) categories which are often classified to be of petrogenic sources (like crude oil spills or seepages) [34]. This is true as the study area experiences exploration activities.

The total PAHs levels (> $1.0 \mathrm{mg} / \mathrm{l})$ in the drinking water sources were high above the NSDWQ guideline value $(0.007 \mathrm{mg} / \mathrm{l})$. The PAHs level was higher in the surface water samples. This suggests inputs from atmospheric deposition of runoffs from coal tar paved roads [9]. PAHs are of major concern in drinking water as they pose serious health problems including mutagenic, toxic and carcinogenic effects amongst others [9].

The contamination level of PAHs as revealed by the present study is medium compared to reports for other locations within the Niger Delta region. For instance, Eduok et al. [35] reported total PAHs level of $7.51 \mathrm{mg} / \mathrm{l}$ for Douglas Creek. On the other hand, Oruambo et al. [36] reported a maximum total of $0.149 \mathrm{mg} / \mathrm{l}$ for several drinking water sources in Akwa Ibom State.

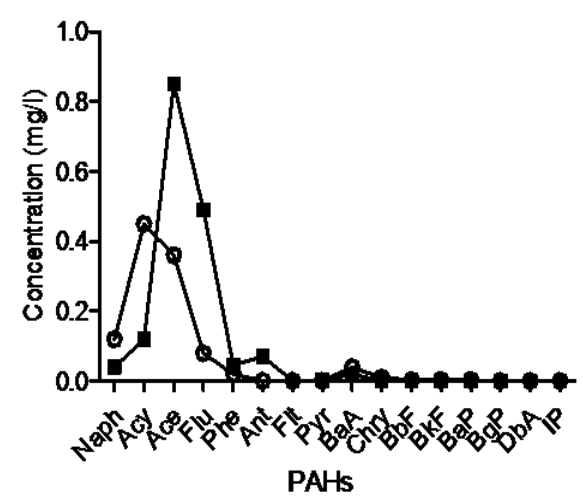

Figure 5. Composition profile of PAHs in the drinking water samples

Table 4. Levels of polycyclic aromatic hydrocarbons (mg/l) in drinking water sources from Okoroette Community

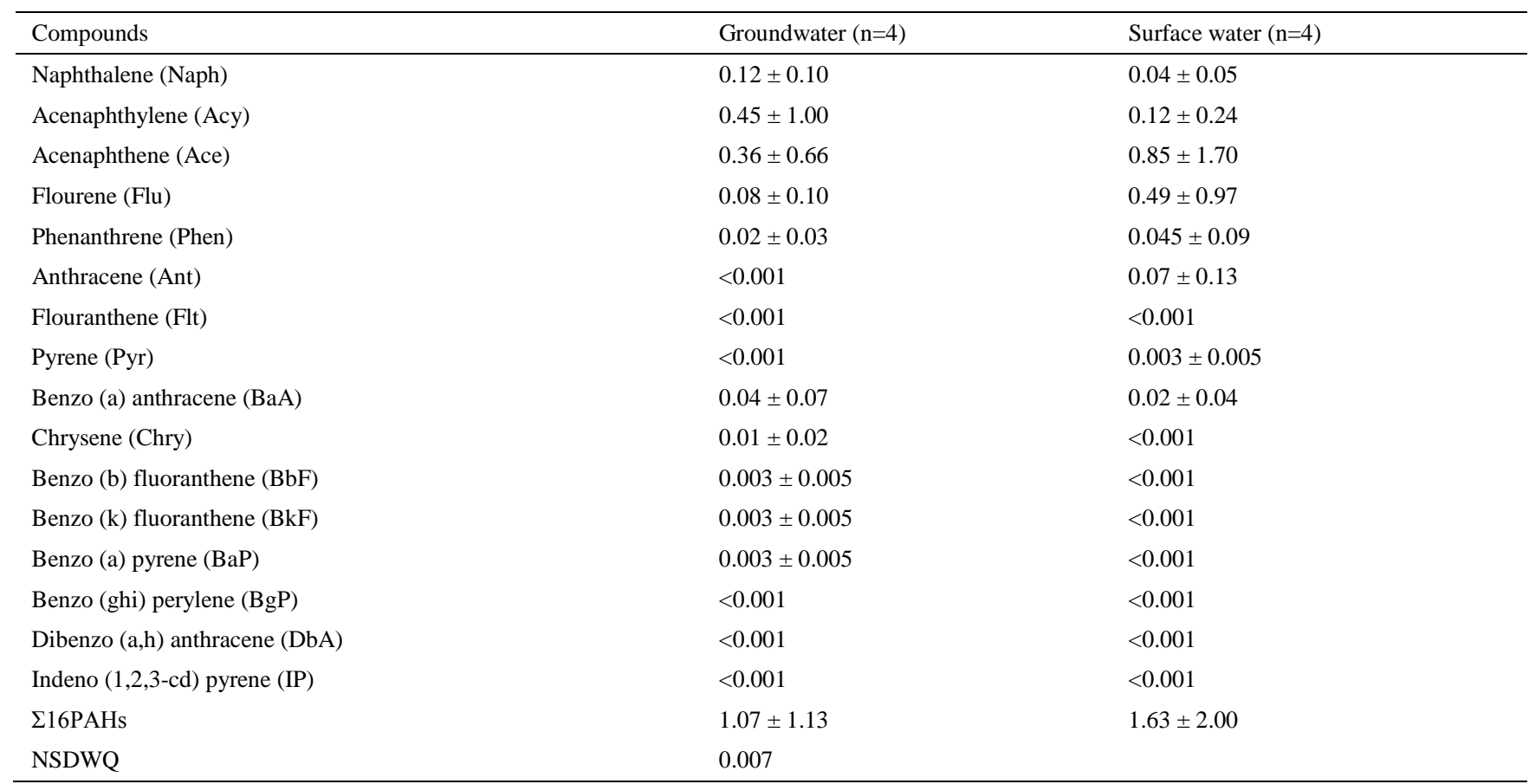


Table 5a. Estimated heath risk of exposure to trace metals in ground water used for drinking in Okoroette community during dry season

\begin{tabular}{|c|c|c|c|c|c|c|c|c|}
\hline & & $\mathrm{Pb}$ & $\mathrm{Cd}$ & $\mathrm{Cu}$ & $\mathrm{Fe}$ & Mn & $\mathrm{Zn}$ & HI \\
\hline \multirow{2}{*}{ Adults } & CDI & $2.29 \mathrm{E}-3$ & $1.00 \mathrm{E}-2$ & $5.52 \mathrm{E}-3$ & $5.39 \mathrm{E}-4$ & 7.95E-3 & $7.81 \mathrm{E}-3$ & \\
\hline & HQ & $6.00 \mathrm{E}-2$ & $2.18 \mathrm{E} 1$ & $1.50 \mathrm{E}-1$ & $7.2 \mathrm{E}-4$ & 5.7E-2 & $2.6 \mathrm{E}-2$ & $2.21 \mathrm{E}+01$ \\
\hline \multirow{2}{*}{ Children } & CDI & $7.28 \mathrm{E}-3$ & 3.47E-2 & $1.76 \mathrm{E}-2$ & $1.7 \mathrm{E}-2$ & $2.54 \mathrm{E}-2$ & $2.5 \mathrm{E}-2$ & \\
\hline & HQ & 2.02E-1 & $6.94 \mathrm{E} 1$ & 4.75E-1 & $2.4 \mathrm{E}-2$ & $1.81 \mathrm{E}-1$ & 8.3E-2 & $7.04 \mathrm{E}+01$ \\
\hline
\end{tabular}

Table 5b. Estimated heath risk of exposure to trace metals in ground water used for drinking in Okoroette community during wet season

\begin{tabular}{cccccccc}
\hline \multirow{3}{*}{ Adults } & & $\mathrm{Pb}$ & $\mathrm{Cd}$ & $\mathrm{Fe}$ & $\mathrm{Mn}$ & $\mathrm{Zn}$ & $\mathrm{HI}$ \\
& $\mathrm{CDI}$ & $1.35 \mathrm{E}-3$ & $1.75 \mathrm{E}-2$ & $1.29 \mathrm{E}-2$ & $4.71 \mathrm{E}-3$ & $1.20 \mathrm{E}-2$ & \\
& HQ & $3.7 \mathrm{E}-2$ & $3.5 \mathrm{E}-1$ & $1.8 \mathrm{E}-2$ & $3.40 \mathrm{E}-2$ & $4.00 \mathrm{E}-2$ & $3.51 \mathrm{E}+01$ \\
\multirow{3}{*}{ Children } & CDI & $4.29 \mathrm{E}-3$ & $5.57 \mathrm{E}-2$ & $4.1 \mathrm{E}-2$ & $1.50 \mathrm{E}-2$ & $3.94 \mathrm{E}-2$ & \\
& HQ & $1.19 \mathrm{E}-1$ & $1.11 \mathrm{E} 2$ & $5.88 \mathrm{E}-2$ & $1.07 \mathrm{E}-1$ & $1.31 \mathrm{E}-1$ & $1.11 \mathrm{E}+02$ \\
\hline
\end{tabular}

Table 5c. Estimated heath risk of exposure to trace metals in surface water used for drinking in Okoroette community during dry season

\begin{tabular}{|c|c|c|c|c|c|c|c|c|}
\hline & & $\mathrm{Pb}$ & $\mathrm{Cd}$ & $\mathrm{Cu}$ & $\mathrm{Fe}$ & $\mathrm{Mn}$ & $\mathrm{Zn}$ & HI \\
\hline \multirow{2}{*}{ Adults } & CDI & $5.39 \mathrm{E}-4$ & $4.31 \mathrm{E}-3$ & $5.39 \mathrm{E}-3$ & $1.32 \mathrm{E}-2$ & $1.48 \mathrm{E}-2$ & $1.06 \mathrm{E}-2$ & \\
\hline & HQ & 1.5E-2 & 8.62E0 & $1.46 \mathrm{E}-1$ & $1.88 \mathrm{E}-2$ & $1.06 \mathrm{E}-1$ & $3.50 \mathrm{E}-2$ & $8.94 \mathrm{E}+00$ \\
\hline \multirow{2}{*}{ Children } & CDI & $1.7 \mathrm{E}-3$ & 1.37E-2 & $1.71 \mathrm{E}-2$ & 4.2E-1 & 4.7E-2 & 3.39E-2 & \\
\hline & HQ & $4.76 \mathrm{E}-2$ & 2.74E1 & 4.63E-1 & $6.0 \mathrm{E}-1$ & 3.34E-1 & 1.13E-1 & $2.90 \mathrm{E}+01$ \\
\hline
\end{tabular}

Table 5d. Estimated heath risk of exposure to trace metals in surface water used for drinking in Okoroette community during wet season

\begin{tabular}{|c|c|c|c|c|c|c|}
\hline & & $\mathrm{Cd}$ & $\mathrm{Fe}$ & $\mathrm{Mn}$ & $\mathrm{Zn}$ & $\mathrm{HI}$ \\
\hline \multirow{2}{*}{ Adults } & CDI & $3.23 \mathrm{E}-3$ & $4.04 \mathrm{E}-3$ & $4.71 \mathrm{E}-3$ & $6.6 \mathrm{E}-3$ & \\
\hline & HQ & 6.46E0 & $5.77 \mathrm{E}-3$ & $3.4 \mathrm{E}-2$ & $2.2 \mathrm{E}-2$ & $6.52 \mathrm{E}+00$ \\
\hline Children & HQ & 2.06E1 & $1.84 \mathrm{E}-2$ & $1.07 \mathrm{E}-1$ & $7.0 \mathrm{E}-2$ & $2.08 \mathrm{E}+01$ \\
\hline
\end{tabular}

Table 6a. WQI for surface water sources in Okoroette, Eastern Obolo

\begin{tabular}{|c|c|c|c|c|}
\hline Parameters & SW1 & SW2 & SW3 & SW4 \\
\hline EC & 35.65 & 21.8 & 40.05 & 15.16 \\
\hline TSS & 0.0025 & 0.026 & 0.042 & 0.09 \\
\hline TDS & 16.5 & 10.8 & 18.0 & 6.0 \\
\hline Cl- & 14.625 & 11.55 & 13.165 & 5.71 \\
\hline DO & 4.17 & 3.755 & 4.05 & 3.14 \\
\hline BOD & 1.17 & 1.28 & 1.225 & 1.22 \\
\hline $\mathrm{pH}$ & 5.215 & 5.52 & 6.52 & 5.97 \\
\hline Hardness & 40.5 & 34.0 & 46.5 & 47.0 \\
\hline Sulphate & 0.201 & 0.213 & 0.2215 & BDL \\
\hline$\sum q n w n$ & 85.77 & 75.98 & 54.18 & 68.12 \\
\hline$\sum w n$ & 1 & 1 & 1 & 1 \\
\hline WQI & 85.77 & 75.98 & 54.18 & 68.12 \\
\hline
\end{tabular}

Table 6b. WQI for ground water sources in Okoroette, Eastern Obolo

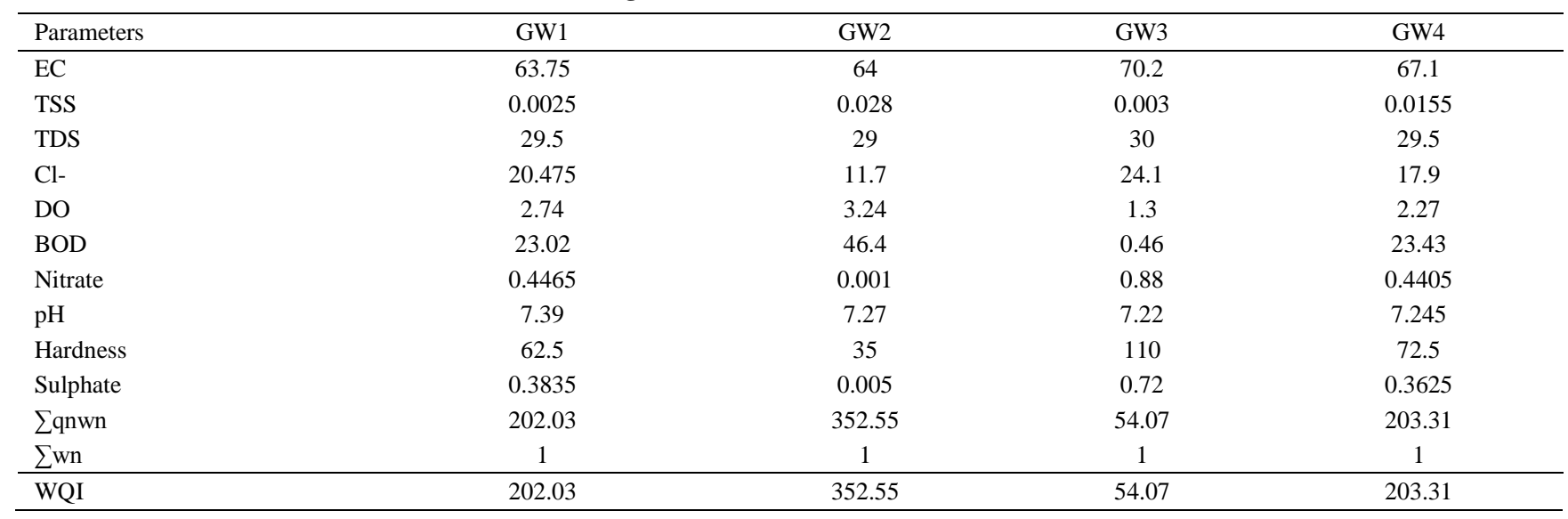




\subsection{Estimated Health Risks}

The results (Chronic Daily Intake (CDI), Hazard Quotient (HQ) and Hazard Index (HI)) of the non-cancer risk assessment of trace metals in drinking are presented in Table 5a to Table 5d. Generally, the calculated hazard indices for ground and surface waters as well as exposed children and adults in dry and wet seasons were greater than 1. This reveals that there are significant risks associated with the drinking water sources in Okoroette Community. Also, the HQ values for cadmium were generally above 1 indicating potential high risk. The HQ values for $\mathrm{Fe}$ were generally the minimum indicating lowest risks associated with the metal in the drinking water sources. The calculated HQ values for other trace metals were below 1 , indicating low risks associated with exposure to them in the drinking water sources.

\subsection{Drinking Water Quality Index}

The results of the calculated water quality indices
(WQI) for water sources in Okoroette community are presented in Table 6a and Table 6b. The results obtained reveal that all the water sources were not suitable for drinking purposes. For the surface water sources, stations SW2, SW3, and SW4 had poor water quality indices of $75.98,54.18$ and 68.12 respectively while SW1 was in the category of very poor water quality with WQI above 76 . In the case of groundwater boreholes, GW3 had a poor water quality while the remaining GW1, GW2 and GW4 were unfit for drinking purposes as the WQI indices exceeded 100.

\subsection{Chemometric Analyses of Water Quality Parameters}

Analysis of variance (ANOVA) revealed that there were significant differences between the physicochemical parameters determined in the analysed samples except for TDS at $p=0.05$. Also, for other determined water quality parameters ANOVA revealed that there were significant differences between the results at $p=0.05$.

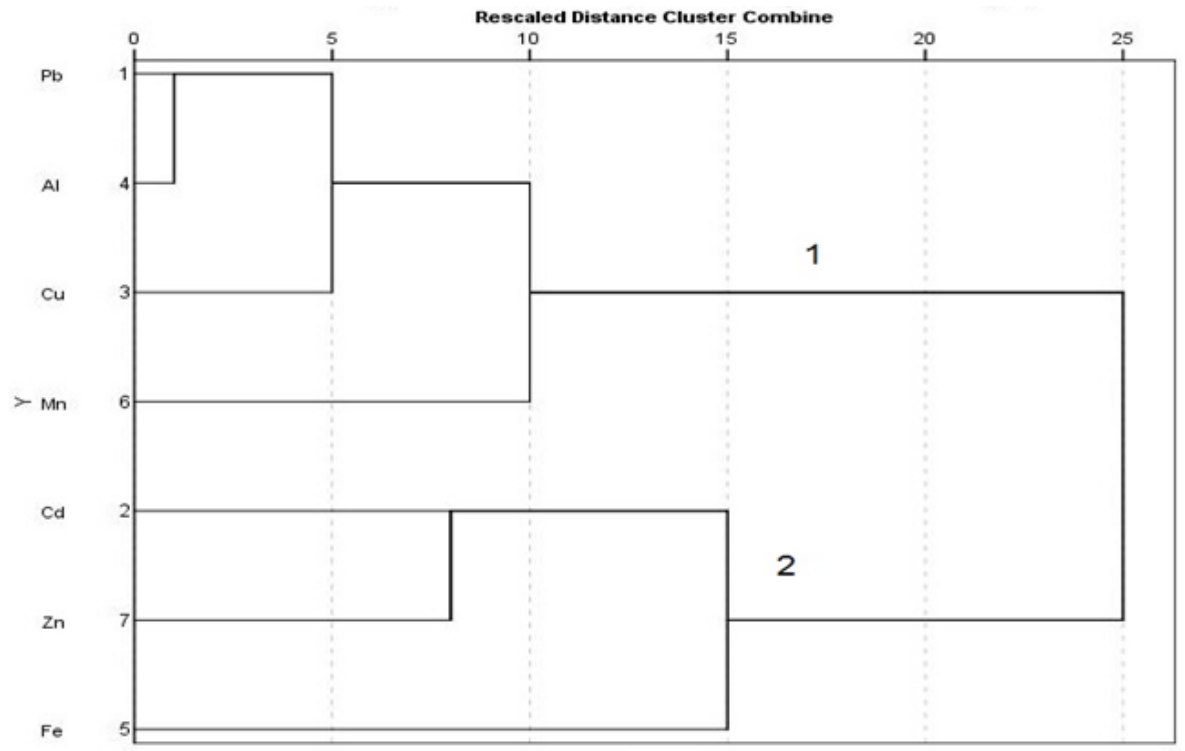

(a)

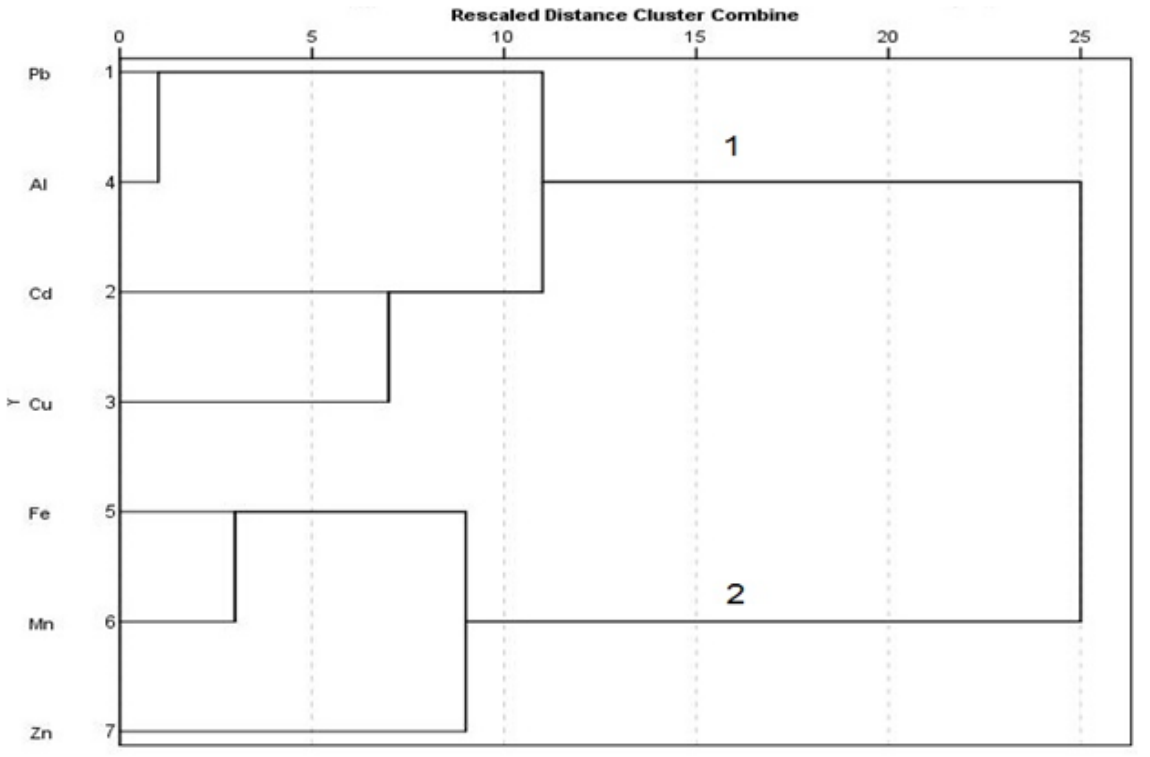

(b)

Figure 6. Source similarities of trace metals in groundwater (a) and surface water (b) 
Pearson's correlation was applied to the results of all the parameters analysed in the drinking water sources in Okoroette community. Significant positive correlation indicates strong relationship or similar origin. Significantly positive correlation exists between TDS and EC; nitrate and temperature; calcium carbonate and turbidity; $\mathrm{Pb}$ and TSS; BOD and PAHs. The relationship between TDS and EC implies that dissolved minerals tend to influence the electrical conductivity of the water samples. Also, nitrate and temperature relationship implies that temperature controls the dissolution of nitrate salts. A factor for $\mathrm{Pb}$ contamination in the area may depend on inputs from suspended solids. BOD as an indicator of organic pollution may provide an avenue for co-occurrence of PAHs in the drinking water sources.

Hierarchical cluster analysis (HCA) is an effective statistical method that helps in the identification of natural homogeneous groups according to similarities or distances and categorises different groups into clusters. Those forming primary clusters may be assumed to be of the same origin or characteristics. In this study, a dendogram was drawn based on Ward's method on the Euclidean distance and was applied to trace metals only. The HCA was conducted using the Statistical Package for Social Sciences (SPSS, version 20.0) software. The source similarities of trace metals in groundwater and surface water are presented in the dendograms in Figure 6.

The two dendograms comprise 2 major clusters each implying different route of contamination for ground and surface water samples. As proposed earlier that the groundwater contamination may be as a result of inputs of metals from their geologic origins, the dendograms on Figure 6a confirms this as $\mathrm{Cd}$ and $\mathrm{Zn}$ formed primary clusters. According to Baird and Cann [37], environmental contamination by $\mathrm{Cd}$ often occurs with $\mathrm{Zn}$ due to their similarities and co-occurrence. The same explanation may be given for $\mathrm{Pb}-\mathrm{Cu}$ relationship observed for cluster 1 in surface water (Figure 6b). The other primary cluster for the groundwater is the $\mathrm{Pb}-\mathrm{Cu}-\mathrm{Mn}$ while $\mathrm{Fe}-\mathrm{Mn}-\mathrm{Zn}$ was also observed for surface water.

Principal component analysis (PCA) is a powerful recognition technique that attempts to explain the variance of a large set of intercorrelated variables with a smaller set of independent variables-principal components. PCA has been frequently employed on large and complex water quality datasets obtained from monitoring studies of surface or ground waters [38]. Factor analysis was conducted to understand the variance and association of the physicochemical parameters as well as other water quality parameters determined in the drinking water sources of the study area. The results are presented in Table 7 . The data set had a wide variance owing to complexity of the parameters and prevailing environmental dynamics. The variances can be classified into three categories, called principal components (PCs).

The first component (PC1) contributes $40.55 \%$ to the total variance with high loadings on $\mathrm{Zn}$, PAHs, Cd, BOD, and $\mathrm{pH}$ (Table 7). This implies that the origin of contamination could be geogenic and organic anthropogenic sources. The second component (PC2) contributes 33.68\% to the total variance with high loadings on EC, salinity, nitrite, calcium carbonate and TDS. This implies that contamination was mainly of dissolved mineral matter. The third component (PC3) contributes $25.77 \%$ to the total variance with high loadings on $\mathrm{Mn}$, THC, temperature and nitrate.
Table 7. Principal component loadings of parameters in ground and surface waters in Okoroette community

\begin{tabular}{|c|c|c|c|}
\hline \multirow{2}{*}{ Parameters } & \multicolumn{3}{|c|}{ Components } \\
\hline & PC1 & PC2 & PC3 \\
\hline $\mathrm{Cu}$ & -.0984 & -0.179 & -0.016 \\
\hline $\mathrm{SO}_{4}{ }^{2-}$ & -0.964 & 0.254 & 0.083 \\
\hline $\mathrm{Zn}$ & $0.954 *$ & -0.299 & 0.027 \\
\hline $\mathrm{Pb}$ & -0.847 & -0.242 & -0.474 \\
\hline TSS & -0.843 & -0.359 & -0.401 \\
\hline PAHs & $0.791 *$ & -0.027 & -0.611 \\
\hline Cd & $0.789 *$ & 0.381 & -0.481 \\
\hline BOD & $0.776 *$ & -0.148 & -0.614 \\
\hline $\mathrm{pH}$ & $0.769 *$ & 0.639 & -0.022 \\
\hline EC & 0.255 & $0.958 *$ & -0.135 \\
\hline $\mathrm{Cl}^{-}$ & -0.214 & $0.953 *$ & -0.215 \\
\hline $\mathrm{NO}_{2}^{-}$ & -0.305 & 0.893* & 0.331 \\
\hline $\mathrm{CaCO}_{3}$ & 0.053 & $0.879 *$ & 0.474 \\
\hline DO & -0.166 & -0.836 & -0.523 \\
\hline TDS & 0.399 & 0.836 & -0.377 \\
\hline $\mathrm{Fe}$ & 0.688 & -0.713 & 0.135 \\
\hline $\mathrm{Mn}$ & 0.134 & -0.189 & $0.973^{*}$ \\
\hline THC & -0.326 & 0.005 & $0.945^{*}$ \\
\hline Temp & 0.013 & 0.392 & $0.920 *$ \\
\hline $\mathrm{NO}_{3}^{-}$ & 0.020 & 0.511 & $0.859 *$ \\
\hline Eigen value & 9.732 & 8.084 & 6.184 \\
\hline Loading \% & 40.55 & 33.68 & 25.77 \\
\hline Cumulative \% & 40.55 & 74.23 & 100 \\
\hline
\end{tabular}

*significant r-values $(\mathrm{p}<0.01)$.

\section{Conclusion}

The present study revealed that the ground and surface water used for drinking in Okoroette community is highly polluted with varied levels of physicochemical parameters, carcinogenic organic (PAHs), and toxic trace metals. Most of the drinking water quality indicators were unacceptable according to IEPA and NSDWQ guidelines and are said to be unfit for drinking purposes. Chemometric characterisation of the water quality indicators reveals that some of the contaminants may be of geogenic and anthropogenic organic in origin. Generally, physicochemical parameters varied between sample locations and seasons and indicated some level of contamination as dissolved oxygen was below recommended limits in all samples analysed. Samples collected during the dry season as well as those of surface water sources tend to contain higher amounts of the target contaminants compared to their counterparts. Trace metal levels revealed low to high contamination with four out of the seven metals analysed exceeded their permissible limits at various intervals. Also, total PAHs exceeded recommended guideline and indicated anthropogenic contamination. The cumulative risks (HI) for all trace metals determined revealed that individuals who consume water from the studied sources stand the risk of toxic effects. The water quality indexes revealed that water from all the sampling stations were not suitable for drinking and domestic purposes. Chemometric analyses helped identify Zn, PAHs, Cd, BOD and $\mathrm{pH}$ as the dominating parameters influencing the water quality in the study area and that contamination source similarities exist between $\mathrm{Cu}-\mathrm{Cd}$ and Fe-Zn. 


\section{Acknowledgements}

Funding support was received from the American Chemical Society (ACS) though the Global Innovation Imperatives (GII) program in 2015. The authors are grateful for technical support received from the Laboratory Services Unit of the Ministry of Science and Technology, Akwa Ibom State, Nigeria.

\section{References}

[1] Obiefuna, G. I.; Orazulike, D. M. Physicochemical characteristics of groundwater quality from Yola Area, Northeastern Nigeria. J. Appl. Sci. Environ. Manag. 2010, 14(1), 5-11.

[2] Atser, J.; Udoh, P. U. Dimension in rural water coverage and access in Akwa Ibom State, Nigeria. Afr. J. Environ. Sci. Technol. 2015, 9 (1), 29-37.

[3] Kadafa, A. A. Environmental impacts of oil exploration and exploitation in the Niger Delta of Nigeria. Global J. Sci. Frontier Res. Environ. Earth Sci. 2012, 12(3), 19-28.

[4] Annual Book of ASTM Standard for Water and Environmental Technology. American Society for Testing and Materials International (ASTM), Pennsylvania, USA, 2012.

[5] Standard methods for the examination of water and waste water, $20^{\text {th }}$ Ed; American Public Health Association (APHA), Washington DC, USA, 2005.

[6] Udosen, E. D. Environmental Chemistry and Pollution Studies; Shalom Ltd: Ikot Ekpene, Nigeria: Shalom, 2015.

[7] Official methods of analysis, $17^{\text {th }} \mathrm{Ed}$; Association of Official Analytical Chemists (AOAC), Washington DC, 1985.

[8] Karyabi, H.; Nasseri, S.; Ahmadkhaniha, R.; Rastkari, N.; Mahvi, A. H.; Nabizadeh, R.; Yunesian, M. Determination and source identification of polycyclic aromatics hydrocarbons in Karaj River, Iran. Bull. Environ. Contam. Toxicol. 2014, 92, 50-56.

[9] Inam, E.; Offiong, N.; Essien, J.; Kang, S.; Kang, S.; Antia, B. Polycyclic aromatic hydrocarbons loads and potential risks in freshwater ecosystem of the Ikpa River Basin, Niger Delta Nigeria. Environ. Monit. Assess. 2016, 188.

[10] Kavcar, P.; Sofuoglu, A.; Sofuoglu, S.C. A health risk assessment for exposure to trace metals via drinking ingestion pathway. Int. J. Hyg. Environ. Health. 2009, 212, 216-227.

[11] Inam, E.; Etim U.J.; Offiong, N.O. Assessment of human health risk associated with the presence of trace metals in groundwater supplies in Akwa Ibom State, Nigeria. Nigeria. World J. Appl. Sci. Technol. 2014, 6(1), 55-65.

[12] Shah, M.T.; Ara, J.; Muhammad, S.; Khan, S.; Tariq, S. Health risk assessment via surface water and sub-surface water consumption in the mafic and ultramafic terrain, Mohmand agency, northern Pakistan. J. Geochem. Explor. 2012, 118, 60-67.

[13] Guidelines for carcinogenic risk assessment; US Environmental Protection Agency (US EPA), Risk Assessment Forum, Washington DC, 2005.

[14] Iqbal, J.; Shah, M.H.; Akhter, G. Characterization, source apportionment and health risk assessment of trace metals in freshwater Rawal Lake, Pakistan. J. Geochem. Explor. 2013, 125, 94-101.

[15] Khan, S.; Cao, Q.; Zheng Y.M.; Huang, Y.Z.; Zhu, Y.G. Health risk of heavy metals in contaminated soils and food crops irrigated with wastewater in Beijing, China. Environ. Pollut. 2008, 152, 686-692.

[16] Muhammad, S.; Sha, M.; Khan, S. Health risk assessment of heavy metals and their source apportionment in drinking water of Kohistan Region, Northern Pakistan. Microchem. J., 2011, 98, 334-343.

[17] Lee, S.W.; Lee, B.T.; Kim, J.Y.; Kim, K.W.; Lee, J.S. Human risk assessment for heavy metals and As contamination in the abandoned metal mine areas, Korea. Environ. Monit. Assess. 2006, 119, 233-244.

[18] Kolluru, R.V.; Bartell, S.M.; Pitblado, R.M.; Stricoff, R.S. Risk Assessment and Management Handbook. Mc-Graw-Hill: New York, 1996.

[19] Etim, E. E.; Odoh, R.; Itodo, A. U.; Umoh, S. D.; Lawal, U. Water quality index for the assessment of water quality from different sources in the Niger Delta Region of Nigeria. Frontiers Sci. 2013. 3(3), 89-95.

[20] International Standards for Drinking Water $3^{\text {rd }}$ Ed; World Health Organization (WHO), Geneva, 2006.

[21] Parameters of Water Quality: Interpretation and Standards; Irish Environmental Protection Agency (IEPA), Wexford, Ireland, 2001.

[22] Nigerian Standard for Drinking Water Quality (NSDWQ). Standard Organization of Nigeria, Abuja, Nigeria; 2007.

[23] National Guideline and Standard for Water Quality in Nigeria; Technical Advisory Committee on Water Quality Criteria; Federal Ministry of Environment (FMENV), Abuja, Nigeria, 1992.

[24] Spiro, T. G.; Stigliani, W. M. Chemistry of the Environment; Prentice Hall: New Jersey, USA, 1996.

[25] Inam, E.; Kim, K. W.; Ebong, G.; Eduok, U. Trace elements in ground and packaged water in Akwa Ibom State, Nigeria. Geosyst. Eng., 13(2), 57-68.

[26] Uzoekwe, S. A.; Oghosamire, F. A. The effect of refinery and petrochemical effluent on water quality of Ubeji Creek Warri, Southern Nigeria. Ethiopian J. Environ. Stud. Manag. 2011, 4(2), 107-116.

[27] Owamah, I. H.; Asiagwu, A. K.; Egboh, S.H. O.; Phil-Usiayo, S. Drinking water quality at Isoko North communities of the Niger Delta Region, Nigeria. Toxicol. Environ. Chem. 2013, 95(7), 1116-1128.

[28] Adekunle, A. A.; Badejo, A. O.; Oyerinde, A. O. Pollution studies on groundwater contamination: water quality of Abeokuta, Ogun State, South West Nigeria. J. Environ. Earth Sci. 2013, 3(5), 161-166.

[29] Udousoro, I. I; Ikpeme, N. E. Chemometric characterisation of surface water quality in Uruan, Nigeria. Int. J. Chem. Stud. 2013, 1(4), 102-112.

[30] Udosen, E. D. Variations in oxygen and some related pollution parameters in some streams in Itu Area of Nigeria. J. Environ. Sci. 2000, 12(1), 75-80.

[31] Itah, A. Y.; Akpan, C. E. Potability of drinking water in an oil impacted community in Southern Nigeria. J. Appl. Sci. Environ. Manag. 2005, 9(1), 135-141.

[32] Florea, A. M.; Büssellberg, D. Occurrence, use and potential toxic effects of metals and metal compounds. BioMetals. 2006, 19, 419-427.

[33] Huang, F.; Schneider, J. S. Effects of lead exposure on proliferation and differentiation of neural stem cells derived from different regions of embryonic rat brain. NeuroToxicol. 2005, 25(6), 1001-1012.

[34] Zakaria, M. P.; Takada, H.; Tsutsumi, S.; Ohno, K.; Yamada, J.; Kouno, E.; Kumata, H. Distribution of polycyclic aromatic hydrocarbons (PAHs) in rivers and estuaries in Malaysia: a widespread input of petrogenic PAHs. Environ. Sci. Technol. 2002, 36(9), 1907-1918.

[35] Eduok, S. I.; Ebong, G. A.; Udoinyang, E. P.; Njoku, J. N.; Eyen, E. A. Bacteriological and polycyclic aromatic hydrocarbon accumulation in mangrove oyster (Crassostrea tulipa) from Douglas Creek, Nigeria. Pak. J. Nutr. 2010, 9(1), 35-42.

[36] Oruambo, I. F.; Brown, H.; Okeh, C. Correlation between exposure to toxic heavy metals in fish, sediment and drinking water, and high incidence of prostate enlargement in Two States of the Niger-Delta, Nigeria. Biochem. Biotechnol. Res. 2014, 2(1), 1-5.

[37] Baird, C.; Cann, M. Environmental Chemistry. 4th ed.; WH Freeman \& Company: New York, USA, 2008.

[38] Kouras, A.; Katsoyiannis, I.; Voutsa, D. Distribution of arsenic in groundwater in the area of Chalkidiki, Northern Greece. J. Haz. Mater. 2007, 147, 890-899. 